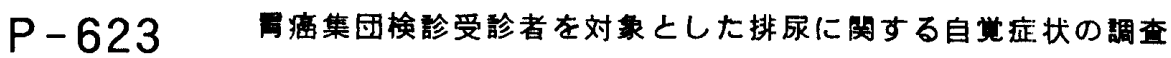

滕枝市立

北川元昭、平野恭弘、福田 健、阿曾佳郎

【目的】近年増加しつつある前立腺疾患とくに前立腺肥大症の治療に関してはめざましいものがあるが、 どの程度の前立腺肥大症が央際にQＯＬの障害に結びつき治療の対象にすべなのかの検討も必要であ る。今回、静岡県藤枝市において前立腺検診を進めていくにあたり事前に排尿状態に関するアンケート を用いて一般住民の日頃の排尿状態を解析し、一般人口のなかに存在する隠れた前立腺疾貟症例の実態 の把握を試みたので報告する。【対象亡方法】藤枝市住民検診においてH 6 年 9 月から12月0)間に胃癌検 診を受診した 30 慼以上の成人男子 944 名を対象に、I - PS Sにもとずいたアンケートにより排尿状態に ついて調査した。【結果】各項目加齢にともない2 点（ 2 回に 1 回未満）以上と回答する割台が多くみら

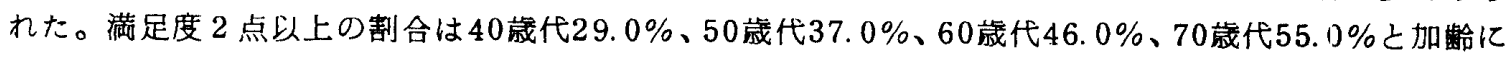
ともない不満が高くなっている傾向がるれた。【考察】排尿状態の解析には、2点以上と回答した項目 が 1 項目でもある症例を前立腺関連症状を有する症例として検討した。その結果、1〜 7末での 7 つの 質問に対してそれぞれ 2 点以上之回答した項目か 1 項目あった場合の頻度は 50 歳代 $32.5 \%$ 、60歳代 $45.3 \% 、 70$ 歳代 $61.4 \%$ であり、ほぼ前立腺肥大症の㠍患率に相当した。前立腺突患のスクリーンを考 えた場合、このような症例を対象に 2 次検診を実施するてとが適当と考えられ今後更に検討を加える予 定である。

\section{$P-624$ 癌集団検讋受跈者を対象とした前立腺検跈}

藤枝市立

福田 健、平野恭弘、北川元昭、阿曽住郎

【目的】前立腺疾患の啓蒙之前立腺癌の早期発見を目的とし、地域医療の向上を目指す。【対象】藤枝 市住民検訩で胃癌検診を受診する50歳以上の男子で、併甘て前立腺検診の希望申し出のあった者。

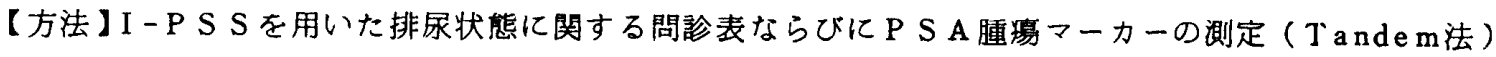

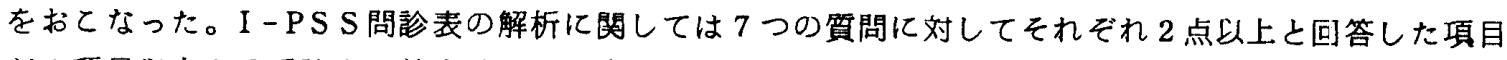
が 1 項目以上ある受衫者を前立腺肥大症有症状者、また P S A 值に関しては $4.0 \mathrm{ng} / \mathrm{m} \ell$ 以.上の症例を

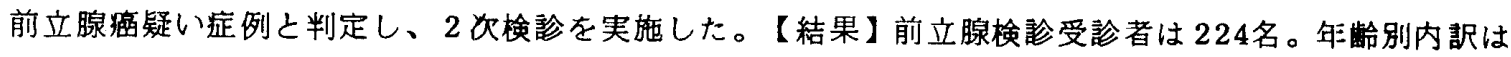
50 歳代 73名、60歳代 103名、70歳代 43名、80歳代5名であった。一次検診判定結果は、前立腺肥大症 疑い症列は 101 名 (50歳代 23名、60歳代47名、70歳代 27名、80歳代 4名) であった。前立腺癌疑い症 例は 32 名 (50歳代 5 名、60歳代13名、70墄代14名)であった。このうち現在までに前立朋肥大症疑い 症例 53 名 $(52.5 \%)$ 、前立腺癌疑い症例 24 名 $(75.0 \%)$ が二次検診を受診した。二次検診の結果、前立 腺肥大症疑い症例中 28 例 $(52.8 \%)$ 亿対し前立腺肥大症の薬物療法を施行した。また前立舆癌疑い症例 中 12 例 $(50 \%)$ 亿前立腺生検を施行し、4例が早期前立腺癌( stage B 2例、stage C 2例) 之診断され た。前立腺癌の発見率は $1.8 \%(4 / 224)$ であった。 